\title{
Critical Aspects of Aquafeed Value Chain in the Kenyan Aquaculture Sector- A Review
}

\author{
Jonathan M. Munguti ${ }^{1}$, James G. Kirimi ${ }^{2}$, Kevin O. Obiero ${ }^{3}$, Erick O. Ogello ${ }^{4}$, Josiah A. Sabwa ${ }^{5}$, Domitila N. \\ Kyule $^{1}$, David M. Liti ${ }^{6}$ \& Levi M. Musalia ${ }^{7}$ \\ ${ }^{1}$ Kenya Marine \& Fisheries Research Institute, National Aquaculture Research Development \& Training Center \\ (NARDTC), P.O. Box 451-10230, Sagana, Kenya \\ ${ }^{2}$ Department of Animal Sciences, Chuka University, P.O. Box 109-60400, Chuka, Kenya \\ ${ }^{3}$ Kenya Marine \& Fisheries Research Institute, Sangoro Aquaculture Research Station, P.O. Box 136-40111, \\ Pap-Onditi, Kenya \\ ${ }^{4}$ Department of Fisheries and Natural Resources, Maseno University, P.O. Box Private Bag, Maseno, Kenya \\ ${ }^{5}$ University of Eldoret, Department Fisheries and Aquatic Sciences, P.O Box 1120-30100, Eldoret, Kenya \\ ${ }^{6}$ University of Eldoret, Department Biological Sciences, P.O Box 1120-30100, Eldoret, Kenya \\ ${ }^{7}$ Department of Dryland Farming and Natural Resources, Tharaka University College, P.O. Box 193-60215, \\ Marimanti, Kenya \\ Correspondence: Jonathan M. Munguti, Kenya Marine \& Fisheries Research Institute, National Aquaculture \\ Research Development \& Training Center (NARDTC), P.O. Box 451-10230, Sagana, Kenya. E-mail: \\ jmunguti2000@gmail.com
}

\author{
Received: March 5, 2021 Accepted: April 12, 2021 Online Published: April 20, 2021 \\ doi:10.5539/sar.v10n2p87 URL: https://doi.org/10.5539/sar.v10n2p87
}

\begin{abstract}
This article reviews critical aspects of the aquafeed value chain in the Kenyan aquaculture sector. Aquaculture production in Kenya has grown steadily in recent years, to more than 18,000 tons in 2019. Due to the growing demand for fish and fish products, there has been a gradual shift from extensive to semi-intensive to moderately intensive aquaculture systems, leading to an increased demand for high quality commercial fish feeds. The current annual demand for fish feed in Kenya is estimated at 34,000 tons. It is the lack of sufficient and high-quality local fish feed production that has created a market for fish feed importers, which is currently estimated at 7,000 tons annually. However, the imported fish feed is expensive for most fish farmers, leading to low production. Local fish feed production through home-based formulation should be driven by fish farmers to contain the rising cost of feeds. Most cottage feed manufacturers produce mash, crumbles or sinking pellets because they lack extruder for making floating pellets, hence the need for quality control in the aqua-feed sector. Fish feed producers are weakly covered by financial services providers, hence the inability to compete effectively with other value chains. The paper outlines five key actors in the aqua-feed value chain from production to marketing. These include; raw material (ingredients) suppliers, feed manufacturers (feed formulators), distributors/wholesalers, retailers, and customers who are fish farmers. We recommend intensification of local aqua-feed production using locally available materials to reduce the importation. This will ensure the long term economic and ecological sustainability of the aquaculture sector. There is a need for favourable policies to lower importation rates for raw materials as a way of boosting the availability of additional feed resources and inputs.
\end{abstract}

Keywords: actors, aqua-feed, value chain, Kenya

\section{Introduction}

Successful aquaculture depends on the sufficient production and supply of quality feeds. Aquafeeds can be classified as direct and indirect (Hasan et al., 2007). The direct aquafeeds include commercially manufactured feeds, on-farm prepared feeds and lower market value fish (discards), while indirect feeds are generated by using fertilizers or manure within the culture systems (Hasan et al., 2007; Tacon \& Metian, 2015). The indirectly generated feeds including live feeds are rich in natural nutrients and are easily ingestible and digestible by 
cultured fish. The live feeds are more crucial for larval fishes that are characterized by smallmouth gap and rudimentary digestive track (Ogello et al., 2020).

Currently, fish feed production is recognized as one of the fastest-growing agricultural sectors in the world (Kong et al., 2020). According to Kumar et al. (2018), the advancement in aquaculture-based technologies, especially in fish feed production and management practices have contributed immensely to the increased production efficiencies for many farmed aquatic organisms. Despite notable variations in production capacities among different countries, aquaculture has collectively realized the highest average growth rate globally (FAO, 2019). In comparison to other forms of food fish production systems, nearly $95 \%$ of global aquaculture production occurs in developing nations at an annual growth rate of $6.13 \%$ (FAO, 2019). The Asian continent produces 102.9 tones ( $91 \%$ ) of the global aquaculture production, whereas the African continent produces close to 2.2 million tones, with aquaculture growing at an annual average rate of $9.81 \%$ since 2000 (FAO, 2019; Tacon, 2020).

Nearly most of the ingredients used in making feeds in aquaculture are imported (Tacon \& Metian, 2015; Tacon, 2020). Initially, many countries relied on indirect natural productivity in their ponds by fertilization, but presently, nearly $70 \%$ of the existing aquaculture systems rely on direct aqua-feeds diets (Tacon, 2020). To attain high fish production in aquaculture, quality feed production is a prerequisite. Fish feed quality is a factor of the presence and balance of essential amino acids, which in turn determine protein utilization (Kirimi et al., 2020; Munguti et al., 2021). Production of quality aquafeeds has been made possible due to the technological advances in feed processing equipment, feeds management practices contributing to aquaculture intensification (Kumar \& Engle, 2016). In essence, quality feeds improve feed conversion efficiencies and lead to high fish yields to levels comparable with the capture fisheries (FAO, 2018; Kok et al., 2020).

In the past decade, aquaculture has been recognized as one of the flagship projects in Kenya capable of stirring the country's economy (Nyonje et al., 2018; Githukia et al., 2020). This has contributed to the increase in aquaculture production in Kenya, which currently stands at about 18,000 tons annually (Figure 1) (KNBS, 2020). Moreover, the rapid increase in population, incomes and constant campaigns on the health benefits associated with fish consumption have contributed to the current increase in the demand for fish (Obiero et al., 2019). The huge demand for fish can be met if aquaculture intensification strategies are initiated and undertaken sustainably (Munguti et al., 2017).

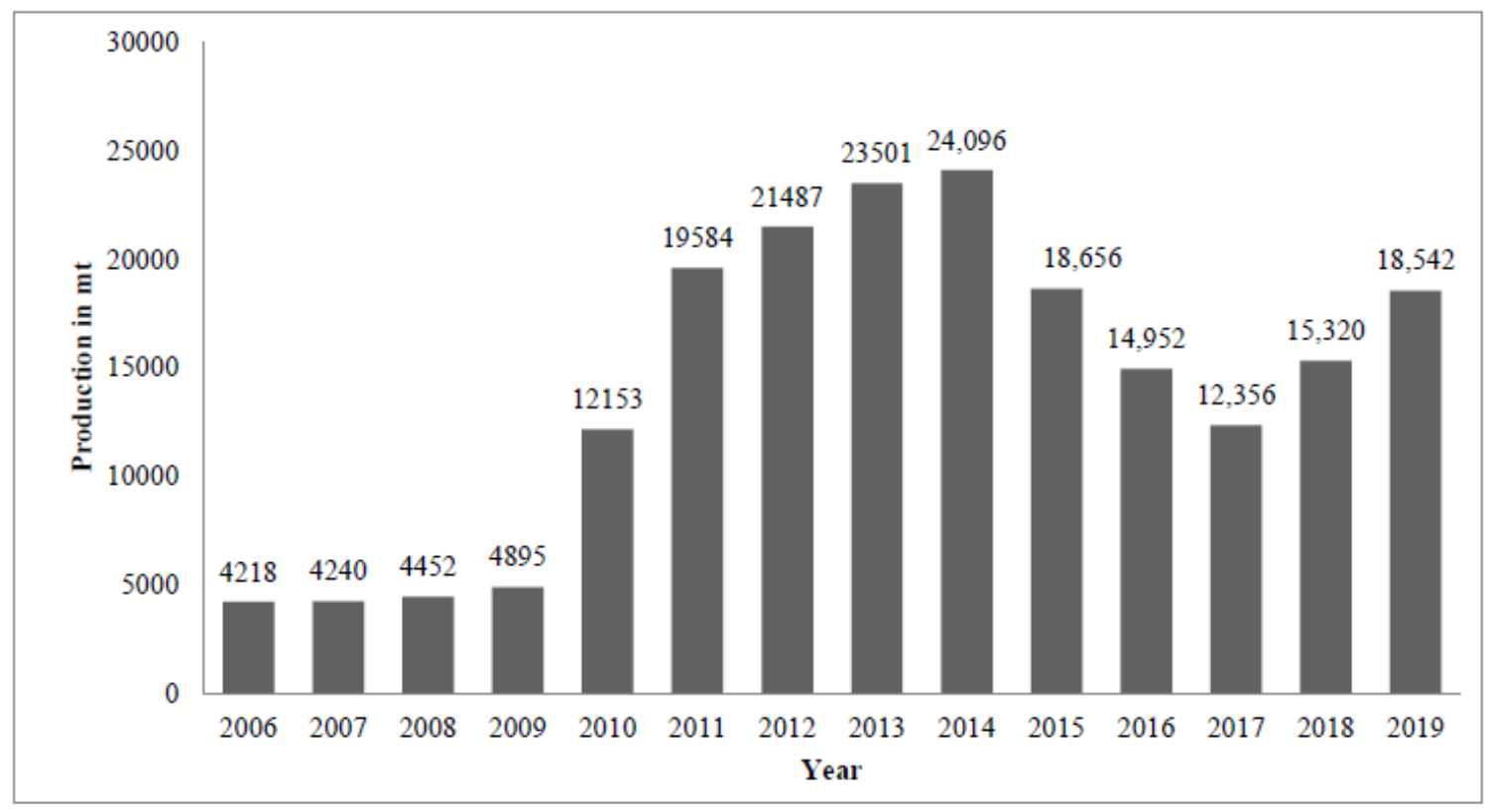

Figure 1. Trends in aquaculture production in Kenya 2006- 2019 (KNBS, 2020)

The growing demand for fish and fish products in Kenya has contributed to a gradual shift from extensive to semi-intensive and moderately intensive aquaculture production systems, leading to an increased demand for quality commercial fish feeds (FAO, 2018). However, the cost of quality feeds is very high for most fish farmers, 
hence the need for cost-effective but quality feeds that provides the nutritional specifications for each species (Kok et al., 2020). Quality fish feeds and fingerlings are currently the major challenges facing Kenyan fish farmers where the former alone accounts for over 50\% of the total production cost (Liti et al., 2005; Munguti et al., 2014b). These challenges result in the overall production of inferior products hence affecting these challenges result in the overall production of inferior products that eventually affect the aquaculture industry.

\section{The Kenyan Aquaculture Value Chain}

Value chain analysis involves the evaluation of the actors and factors that impact the performance of a firm, and relationships among participants to recognize and overcome the major constraints to the expanded proficiency, productivity and competitiveness (Fries, 2007). This performance relies upon the actors, how they identify with one another, how data streams and who controls the value chain (Sturgeon, 2001). In fisheries and aquaculture value chain analysis deals with how the sector receives raw materials as input, add value to them through various processes and sell the finished products to end-users (De Silva, 2011). Aquaculture value chain studies regularly incorporate concerns with value chain structure, most ordinarily conveyed through mapping exercises as well as the conduct of value chain actors (Asiedu et al., 2016; Pomeroy et al., 2017). Coordination in a value chain is the estimates that players make in a market system to act in a correlative manner towards a shared objective and spotlights on the types of relationships between actors (Poulton et al., 2004; Kaminski et al., 2017). Aquaculture is an essential area of the economy that has a high potential to give nutritious food and add to the national economy. Through the value chain linkages, aquaculture adds to socio-economic development, improvement of livelihoods and reduction of poverty (Wangila et al., 2007; Ogello \& Munguti 2016). The aquaculture value chain also furnishes policymakers and stakeholders with a methodical apparatus that permits them to comprehend the related processes in the industry and help with advising policy dialogue and investment operations (Asiedu et al., 2015).

Nonetheless, given the nature of aquaculture systems in Kenya, limited investments have been made by actors in the value chain specifically into the quality of inputs and services needed for improvement. In the aqua-feed sector, a steady supply of good quality feed in adequate quantity is often compromised by several factors; key among them is the production of low quality feeds by corrupt fish feed makers (Kirimi et al., 2016; Nalwanga et al., 2009). Likewise, the importation of raw materials increases the cost of feed production, pushing the cost of feeds past the reach of many small-scale farmers. Due to the high cost of quality feeds, most farmers who practise subsistence aquaculture regularly utilize inferior quality home-made feeds that limit the production potential of the culture systems. The cage culture on the other hand in Lake Victoria has presented an intriguing measurement with regards to fish feed interest in Kenya. Most cage operators combine commercial feeds with locally formulated diets or simply use raw feed materials such as Caradina niloticus as direct feeds to minimize production cost. However, the culture period is constantly broadened (sometimes to 9 - a year) as the fish take longer to reach the market size.

\section{Actors in the Aqua-Feed Value Chain in Kenya}

There are five key actors in the aqua-feed value chain from production to marketing. These actors include 1) raw material (ingredients) suppliers, 2) feed manufacturers (feed formulators), 3) distributors/wholesalers, 4) retailers, and 5) customers who are the fish farmers. As per Porter (1998), for any value chain to be attainable, actors need to work together without a single business entity traversing the whole chain operation. Hence all actors work together closely from the provision of raw materials to the final consumption of the finished product.

\subsection{Raw Materials/Ingredients Suppliers}

Suppliers of fish ingredients are significant actors in the aqua-feed value chain. They produce and sell milling by-products (cereal by-products) such as maize bran, wheat germ, middlings, rice bran, rice polishings, wheat bran, hominy feed (maize bran with maize germ) and oilseed meals e.g soybean meal, canola meal, sunflower meal which are the raw material in aqua-feed manufacturing. They additionally avail raw materials from inside and outside the nation to feed manufacturers. However, the expense of the raw materials from local millers is higher as compared to those imported from millers within the East African region and beyond. Thus, it is a typical practice for small-scale feed processors to import ingredients from other countries. There is a need to address the many constraints in aqua-feed ingredients acquisition and hence give solutions that guarantee feed safety and quality and in turn, guarantees public health safety and higher fish production. Many marketing agents adulterate animal feed raw materials before selling. Secondly, as these ingredients move down the supply chain their crude protein levels reduce due to poor storage. Ingredients from landing sites and oil mills have better nutritional quality than ingredients from stores and shops (Nalwanga et al., 2009; Kirimi et al., 2016). In the case of soybean meal and bran, sawdust is usually added others add coffee husks in rice bran. In some instances, the 
suppliers add even sand to fishmeal a phenomenon that is normally reflected by low crude protein, high crude fibre and increased ash in these ingredients (Nalwanga et al., 2009). The acquisition of these adulterated feed ingredients leads to the formulation of low-quality feeds which eventually affects negatively the growth performance and yields of the cultured fish (Kirimi et al., 2016).

\subsection{Feed Producers/Manufacturers}

Fish feed producers convert raw aqua-feed materials into finished feed products for the specific fish species. There are several commercial fish feed manufacturers in Kenya (Table 1) and a negligible number of farm-made cottage feed producers. The large milling companies are mainly found in towns and have established distribution depots in most urban centers or use leading agro vet stockists and aqua-shops as main distribution outlets. Commercial feed manufacturers typically produce animal feeds for aquatic (2\%) and terrestrial animals (34\% livestock and 64\% poultry) (Figure 3). In Kenya, few companies manufacture aquafeed for all life stages of fish. The feed is manufactured as per the nutrient requirement of fish species. However, the proximate composition of the feed changes according to the size of the fish, with protein, lipid and gross energy reduce with fish size (NRC, 1993). Table 2 shows a list of fish feed manufacturers in Kenya.

Table 1. List of Aqua-feed Manufacturers in Kenya

\begin{tabular}{|c|c|c|c|c|c|c|}
\hline $\begin{array}{l}\text { Fish Feed } \\
\text { Manufacturer }\end{array}$ & Location & $\begin{array}{l}\text { Distribution } \\
\text { Location }\end{array}$ & $\begin{array}{l}\text { Feed Production } \\
\text { Level (MT/Month) }\end{array}$ & $\begin{array}{l}\text { Production Capacity } \\
\text { (MT/Month) }\end{array}$ & Type of Feed & $\begin{array}{l}\text { Fish Farmers } \\
\text { Served }\end{array}$ \\
\hline $\begin{array}{l}\text { Jewlet (Feed) } \\
\text { Enterprises Ltd }\end{array}$ & Kendu Bay & Nationally & 40 & 500 & $\begin{array}{l}\text { Floating and } \\
\text { sinking pellets }\end{array}$ & 1,000 \\
\hline $\begin{array}{l}\text { Tigoi Fish } \\
\text { Feed Company }\end{array}$ & Kakamega & Vihiga County & 1 & * & Sinking pellets & 200 \\
\hline Matayos Aquafeed SHG & Busia & Busia County & 2 & $*$ & Sinking pellets & 350 \\
\hline $\begin{array}{l}\text { Nyawara Animal } \\
\text { Feed Plant }\end{array}$ & Gem, Siaya & Nationally & 10 & $*$ & Sinking pellets & $>50$ \\
\hline Deje Farm Products & Sega, Siaya & $\begin{array}{l}\text { Siaya and } \\
\text { Busia }\end{array}$ & 1 & $*$ & Sinking pellets & $>100$ \\
\hline $\begin{array}{l}\text { Awino Fish } \\
\text { Feed Limited }\end{array}$ & Siaya & Siaya & 1 & $*$ & Sinking pellets & 15 \\
\hline Sare Millers & Kisumu & Vihiga County & 15 & $*$ & $\begin{array}{l}\text { Floating and } \\
\text { sinking pellets }\end{array}$ & 70 \\
\hline $\begin{array}{l}\text { Kenya Marine } \\
\text { and Fisheries } \\
\text { Research Institute }\end{array}$ & Sangoro & Nationally & 4 & 48 & $\begin{array}{l}\text { Floating and } \\
\text { Sinking pellets }\end{array}$ & 200 \\
\hline Nyanjiga Farm & Siaya & Nationally & 10 & $*$ & $\begin{array}{l}\text { Pelletizer, } \\
\text { Mixer, Miller }\end{array}$ & 200 \\
\hline $\begin{array}{l}\text { Mabro Fish } \\
\text { Feed Enterprise }\end{array}$ & Bondo Siaya & Bondo, Siaya & 6 & $*$ & $\begin{array}{l}\text { Hammer, } \\
\text { Mixer, pelletizer }\end{array}$ & 70 \\
\hline Aqualife Solutions & Machakos & Nationally & 20 & 500 & Floating pellets & 50 \\
\hline Sigma Feeds Limited & Rongai & Nationally & 72 & 10,000 & Floating pellets & $>$ \\
\hline Javarih Holdings & Nyamonye, Siaya & $\begin{array}{l}\text { Nyanza } \\
\text { Region }\end{array}$ & Nil & $*$ & Sinking pellets, & 20 \\
\hline Unga fish feeds- Nairobi & $\begin{array}{l}\text { Industrial Area } \\
\text { Nairobi }\end{array}$ & Nationally & 300 & 5,000 & Floating pellets & $>200$ \\
\hline Lenalia Feeds - Limuru & $\begin{array}{l}\text { Limuru } \\
\text { Kiambu }\end{array}$ & Nationally & 40 & 1000 & $\begin{array}{l}\text { Floating and } \\
\text { sinking pellets }\end{array}$ & $>100$ \\
\hline $\begin{array}{l}\text { Bidii Fish Feeds } \\
\text { Luanda(not producing) }\end{array}$ & Emuhaya, Vihiga & $\begin{array}{l}\text { Western/Nyanza } \\
\text {-Kenya }\end{array}$ & 5 & 100 & $\begin{array}{l}\text { Floating and } \\
\text { sinking pellets }\end{array}$ & $>70$ \\
\hline $\begin{array}{l}\text { The total tonnage of local } \\
\text { capacity production }\end{array}$ & & & & 17,148 & & \\
\hline
\end{tabular}

NB. *means data not available

\subsection{Feed Distributors/ Feed Wholesalers}

Feed distributors are intermediaries between feeds manufacturers and farmers. They coordinate themselves as wholesalers, who sell to retailers, other merchants and commercial users, but do not sell in significant amounts to the final consumers (Kotler, 1997). Some feed producers (like Unga feed limited and Sigma feeds) have distribution outlets mainly major Agrovets stockists and aqua-shops located in major towns where farmers can easily access the feeds directly. These stockists eventually sell to smaller agro-vets at a wholesale price while selling to farmers at a retail price. Other feed producers deliver the feeds directly to their clients at factory price. 


\subsection{Retailers}

They retail fish feed and feed ingredients as demanded by the farmers or small-scale feed producers. Some also offer advisory services to farmers. Unlike wholesalers, they sell different types of feed ingredients and feeds, either unpacked or repacked in smaller quantities. Whereas the stockists are well distributed in local areas, the bulk of the stock value is found in the urban centres (Musalia et al., 2007).

\subsection{End-users/ Consumers}

Both grow-out fish farmers and hatchery producers are the main actors in the aquaculture industry. The majority buy branded feeds from agrovet stockists/ aqua-shops. Other farmers utilize feeds acquired from the feed mills or traders. Some of the problems stockists face in accessing their stocks to farmers include long-distance travelled by farmers, farmers are not aware of the feeds, high prices among many others (Musalia et al., 2007). High quality feeds are usually very expensive and remain unaffordable to many farmers. The high cost can be attributed to high taxes imposed on the entire food production sector. This makes farmers' look for cheaper but low-quality alternatives hence affecting their production efficiency negatively (Chadd et al., 2002). Most farmers are increasingly formulating their feeds at the farm level without considering the quality of the ingredients so long as they are assured of their availability.

\section{Sources of Aqua-Feed Raw Materials}

\subsection{Locally Produced Raw Materials for Fish Feeds}

Production of high-quality feeds requires the availability of ingredients of high quality. Currently, the major animal protein source for aquafeeds production in Kenya is the Rastrineobola argentea, locally known as 'Omena', and freshwater shrimp, Caridina nilotica, locally known as 'Ochonga'. However, the availability of these resources depends on other factors such as weather seasonality, government-imposed fishing ban among others (Aloo, 2006). Irregular production of the protein sources is a major bottleneck for the sustainable production of aquafeeds. The bulk of ingredients utilized in feed formulation are by-products from cereals and oilseed industries whose availability depends on weather conditions and climate change. This meddles with the supply of raw materials needed for both farm-made and commercial based fish feed manufacturers, consequently directly impacting the final cost of the aqua-feed products (Munguti et al., 2014b).

The supply of ingredients used in the aqua-feed formulation faces competition from other livestock production systems like poultry and dairy production. Besides, single-ingredient feeds lack certain macro-and micronutrients, have anti-nutritional factors and have poor palatability, which prompts low fish growth (Munguti et al., 2014b). The majority of the animal feed manufacturers are livestock feed manufacturers but only a few deals with fish feed hence a huge setback to fish farmers (Nalwanga et al., 2009; Gitonga, 2014).

\subsection{Imported Raw Materials}

The animal feed industry in Kenya generally depends on imported feed ingredients for example maize, maize, wheat and rice by-products, soybean and its derivatives, sunflower, cotton and nut cakes, fishmeal, and micro-ingredients typically utilized as additives (examples include chemical preservatives, vitamins, antibiotics, minerals, fermentation products among many others) acquired from the East African Community (EAC), regional market and other international markets. Nonetheless, imported fish feeds are popular in Kenya despite the high cost due to the perceived quality of feed ingredients (Nalwanga et al., 2009). The high cost is a consequence of increased demand for these ingredients, competition from the animal feed industry, human food needs and other industrial requirements such as the production of bio-fuel. Slight changes in trade policies in the source countries have conceivably influenced the accessibility and cost of animal feed in Kenya. Importation of raw materials increases the price of feed, making it costly especially for small-scale farmers (Munguti et al., 2021). 


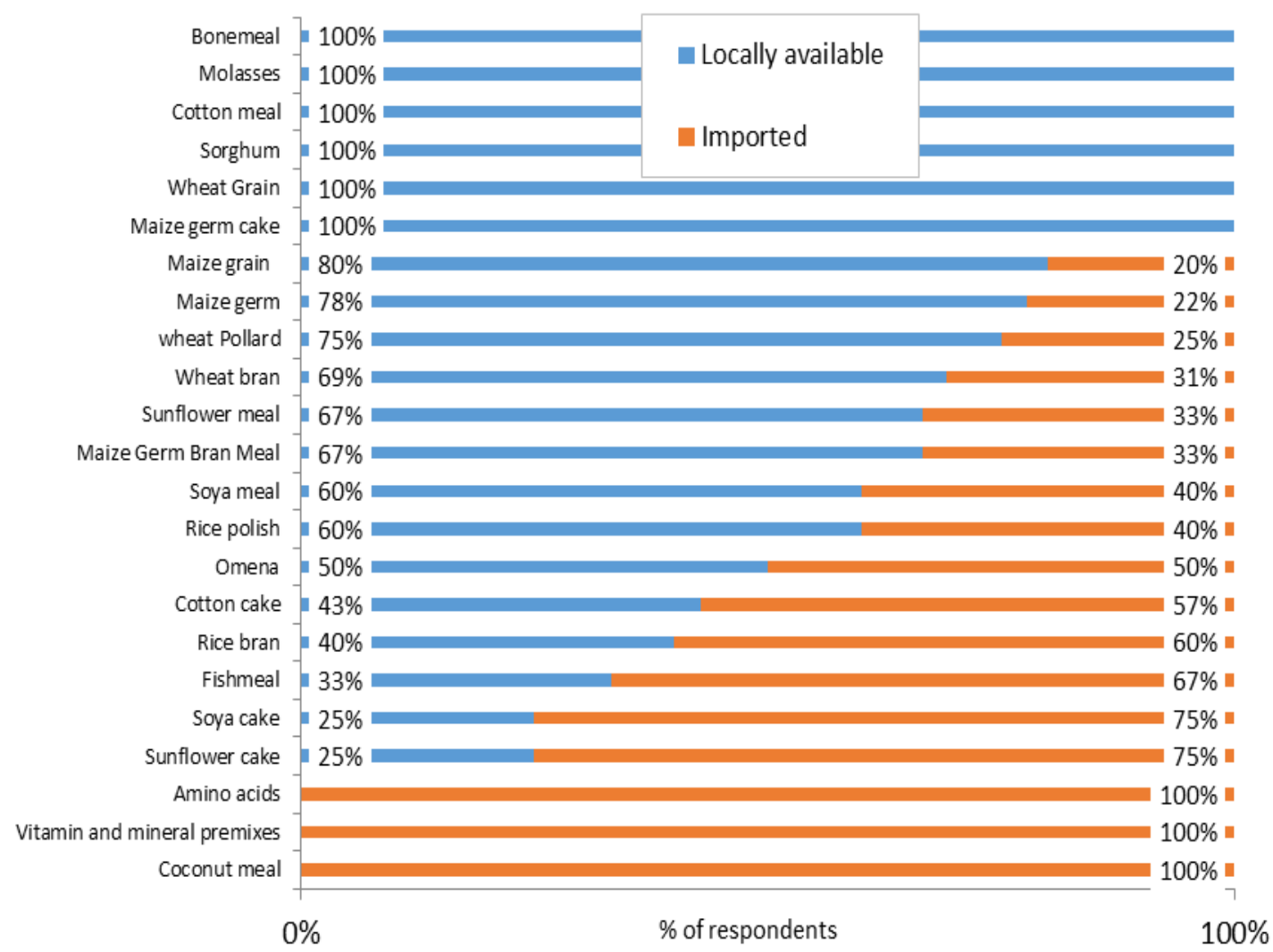

Figure 2. Quantities of locally available and imported fish feed ingredients in Kenya (KMT, 2017)

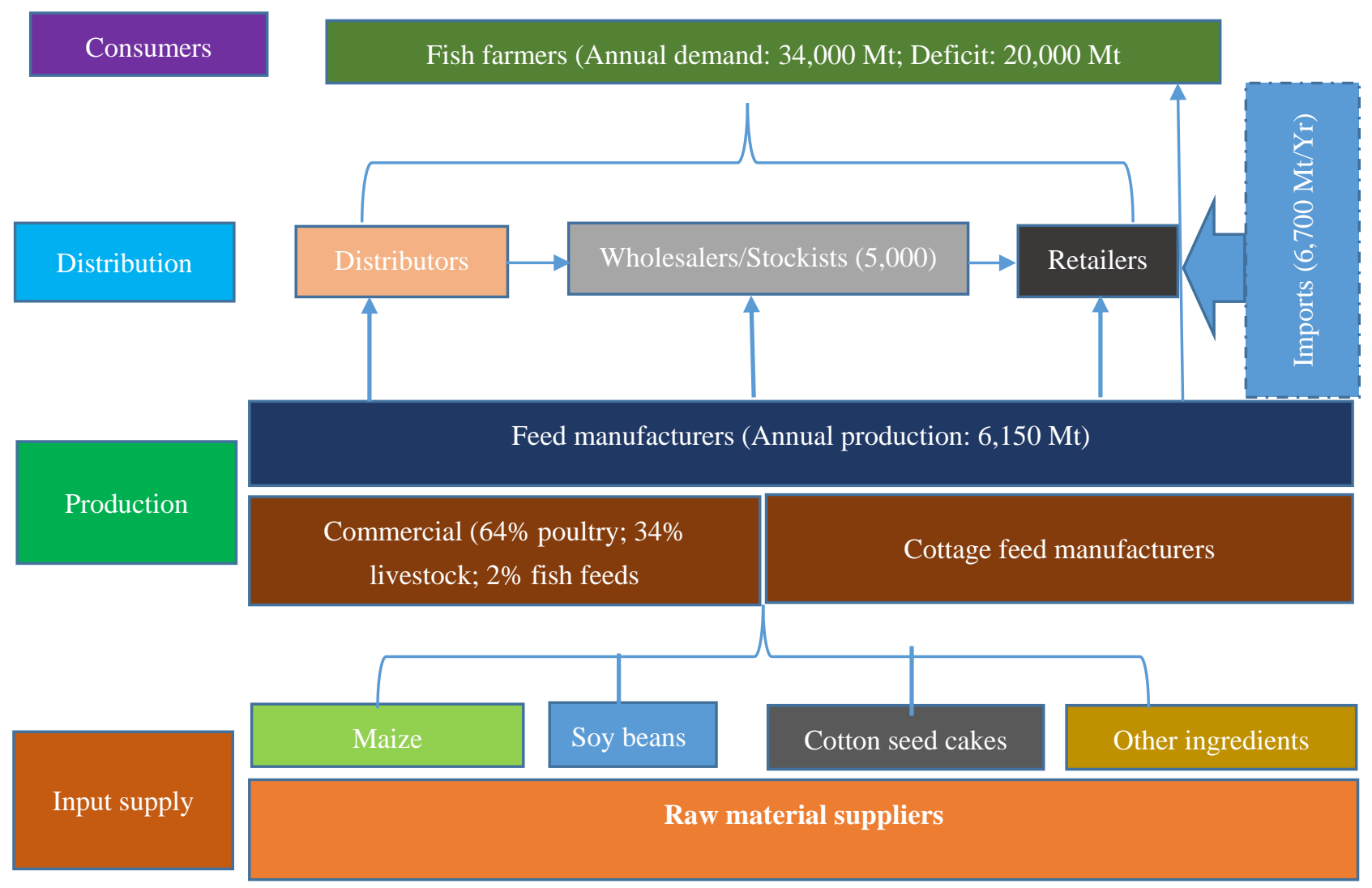

Figure 3. Aquafeed value chain in Kenya 
Table 2. List of Fish Feed Importers and Imported Quantities in Kenya

\begin{tabular}{|c|c|c|c|c|c|}
\hline & $\begin{array}{l}\text { Fish Feed } \\
\text { Manufacturer }\end{array}$ & $\begin{array}{l}\text { Local Dealer/ } \\
\text { Representative }\end{array}$ & $\begin{array}{l}\text { Distribution } \\
\text { Location } \\
\end{array}$ & $\begin{array}{l}\text { Feed Imported } \\
\text { Mt/ pa }\end{array}$ & $\begin{array}{l}\text { Feed } \\
\text { type }\end{array}$ \\
\hline 1 & Aller Aquafeeds-Denmark & $\begin{array}{l}\text { Cage farms Mwea Aqua Fish Farm Kirinyaga } \\
\text { Sare Millers Limited, Kisumu }\end{array}$ & Siaya, Usenge & 250 & Extruded feeds \\
\hline 2 & Rannan Fish feeds Israel & Samaki Express Limited, Nairobi & Nationally & 156 & Extruded feeds \\
\hline 3 & Novatech fish feeds- zambia & Victory farms & Homabay & 400 & \\
\hline \multirow[t]{6}{*}{3} & $\begin{array}{l}\text { Skreting fish feeds - } \\
\text { the Netherlands }\end{array}$ & (I) Victory farms & Homa Bay & 4500 & Extruded feeds \\
\hline & & (II) Unga fish - (catfish) & Nationally & 27 & Extruded feeds \\
\hline & & (III) Starter tilapia & Nationally & 130 & \\
\hline & & (IV) Starter catfish & Nationally & 100 & \\
\hline & & (V) Kamuthanga- Machakos & Machakos & 156 & Extruded feeds \\
\hline & & (VI) Fresh catch - Athi River & Athi River & 102 & \\
\hline \multirow[t]{2}{*}{4} & LFL Riche Terre - Mauritius & (I) Africa blue & Bondo & 100 & Extruded feeds \\
\hline & & (II) Pindu Fish farm & Kiambu & 26 & \\
\hline 5 & Laguna brazil & Jewlet enterprises & Homabay & 600 & Extruded feeds \\
\hline \multirow[t]{2}{*}{6} & Prime feeds - Israel & Africa blue & Bondo & 100 & Extruded feeds \\
\hline & Biomar - France & (I) Starter diet-Makindi fish farm Thika & Thika & & \\
\hline 7 & $\begin{array}{l}\text { Novatech fish } \\
\text { feeds- Zambia }\end{array}$ & Victory Farms Limited & Nairobi & 250 & Extruded feeds \\
\hline 8 & Skretting - Egypt & Fresh Catch Limited & Nairobi & 122 & Extruded feeds \\
\hline 9 & Aller Aqua - Egypt & Fresh Catch Limited & Nairobi & 25 & Extruded feeds \\
\hline
\end{tabular}

\section{Fish Feed Millers}

Fish feeds in Kenya are majorly produced by the private sector; however, both public sector/ state corporations and parastatals are also in the sector.

\subsection{Government Millers}

The bulk of aqua-feed in Kenya is produced by the private sector. However, the development of quality diet formulations for freshwater fish has recently started with the support of an extrusion feed factory at the Kenya Marine and Fisheries Research Institute (KMFRI), Sangoro station. The aim is to support the expanding aquaculture sector to fulfil the increasing demand for affordable, safe, and high-quality fish products. In any case, the government ought to guarantee that Aquaculture feed producers centre around the increased utilization of locally available feed resources and reduce the use of imported feed resources and other inputs. This if done ensures a long-term economic and ecological sustainability of the sector. The government can also come up with the right policies that would lower importation rates as a way of boosting the availability of additional feed resources and inputs.

\subsection{Private Millers}

There are few commercial fish feed producers in Kenya. The major feed producers are Unga and Sigma companies. Due to the monopoly enjoyed by the two companies, there is the development of unregulated production of aqua-feeds, including home-made feed that is likewise sold to other farmers.

\section{On-Farm Feed Production}

Farm-made range from basic feed mixtures composed of one or more feed ingredients, moist or cooked feed ingredient mixtures that form semi-moist feed ball or pellets and nutritionally complete formulated diet produced as dry pellets(Hasan et al., 2007; Hasan \& New, 2013). The development of locally produced feeds is due to the desire of farmers to contain the increasing cost of feeds (Gitonga, 2014; Munguti et al., 2021). In Kenya, most fish farmers who make their feeds produce them in mash form, crumbles or sinking pellets because they lack extruder for making floating pellets (Nyandat, 2007; Munguti et al., 2014b). Some farmers use improvised pelletizing machines or meat mincing machines and local feed grinders when making their feeds. In most cases, issues relating to the quality of these feeds end up compromising water quality, fish health and growth. Farmers often produce these feeds in low quantities that barely meet their farm-level needs. The quality of these feeds is also compromised especially due to the lack of drying facilities, awareness and knowledge in feed formulation for the different growth stages of fish among many others. 


\section{Services in the Aquaculture Feed Value Chain}

\subsection{Financial Services}

The government of Kenya empowers aquaculture advancement by offering credit facilities through the Agriculture Finance Corporation (AFC). However, the level of credit utilized in aquaculture is very low (Quagrainie et al., 2010). The majority of fish farmers can access commercial banks and Saccos to deposit cash derived from the sale of their fish. Access to credit facilities remains a challenge to most of the farmers thus making it very difficult to expand their enterprises. The use of credit facilities by Kenyan fish farmers is very low (Quagrainie et al., 2010). This is an issue that requires extensive consultations with the relevant stakeholders including insurance companies. There is also a need for capacity building. Traditional agricultural businesses entities like dairy and others can easily access credit from lending institutions, unlike aquaculture enterprises. Only a few financial institutions offer loans to fish farmers, perhaps due to perceived high production risks in aquaculture (Ngugi \& Manyala, 2004; Quagrainie et al., 2009).

\subsection{Extension, Information Services and Capacity Building}

The State Department of fisheries and the blue economy and directorate of fisheries at County levels are responsible for extension support and information services to farmers. Fisheries officers offer extension and information services. They also train and advise farmers during farm visits, on-farm demonstrations, and other training sessions organized at both county and national levels. Non-governmental organizations and feed providers also provide extension services to farmers through field demonstration and seminars/workshops (Musalia et al., 2007). In his study farmers got information in the following order; training and field demonstrations (57\%), visits to other farms (22\%) and attendance at shows (21\%) (Musalia et al., 2007).

\subsection{Quality Control in the Aqua-Feed Sector}

The quality of commercial feed is assessed in terms of its nutritional composition as well as the presence or absence of substances that may be harmful to both human and animal health (Gitonga, 2014). The supply of high-quality fish feed is compromised by several factors. For instance, some deceitful and corrupt fish feed manufacturers produce low-quality feeds and sell them to clueless farmers (Kirimi et al., 2016). Notwithstanding, the Government of Kenya $(\mathrm{GoK})$ assumes a significant part in supporting the improvement of the aquaculture sector through the development and implementation of policies and regulations in the fish feed sector. Kenya Bureau of Standards (KEBS), which is a government agency, regulates standards, however, many feed operators and ingredient suppliers are not registered with the institution. Registration will make the operators and the suppliers apply for standardization specifications for specific feed products before releasing them into the market hence assuring of quality. Smaller feed processors are unregistered, unregulated and hard to follow, consequently evading the oversight of KEBS.

With feed cost continuing to rise, ensuring the quality, cost-effectiveness, availability, and optimization of their use, should all be considered as important factors to the promotion of continued growth in the sector. There is a need to allow the fish feed actors to follow the laid down regulations that will check and validate their products to ensure quality. Some fish feed producers have employed competent technical personnel who deal directly with feed formulation and quality assurance. The feed formulation and quality assurance specialists entirely work on feed composition, proximate analysis and interpretation of the analysis. A majority of the feed producers rarely engage these experts hence compromising the fish feed quality (Munguti et al., 2014a).

\section{Conclusion}

This paper characterizes the aquafeeds value chain and distinguishes limitations to its supply and use in Kenya. Some of the challenges associated with the animal feed industry include an erratic supply of raw materials, lack of standardization, and low quality of ingredients. The government ought to establish an enabling environment for the different players in the fish feed industry especially the existing and potential investors. This will involve the ease of registering these feed companies and producers, easy access to credit and other support services to all the players in the value chain. Support research, development and policy for local production of raw materials for feed manufacturing. Additionally, collaboration among actors in the aqua-feed value chain is critical to supply quality and adequate quantity feed, improve its competitiveness and profitability. The level at which farmers' utilize credit facilities is still very low. Hence there is a need to educate farmers, government agricultural lending agencies and other commercial agricultural lenders to put resources into this venture.

\section{References}

Aloo, P. (2006). Fishery industry in Kenya: Towards the development of a national policy. FAO Nairobi, Kenya. 
Asiedu, B., Failler, P., \& Beyens, Y. (2015). The performance of tuna processing fishery sector to sustainable fish trade and food security in Ghana. Journal of Energy and Natural Resource Management, 2(1), 8-14. https://doi.org/10.26796/jenrm.v2i0.39

Asiedu, B., Failler, P., \& Beyens, Y. (2016). Enhancing aquaculture development: Mapping the tilapia aquaculture value chain in Ghana. Reviews in Aquaculture, 8(4), 394-402. https://doi.org/10.1111/raq.12103

Chadd, S. A., Davies, W. P., \& Koivisto, J. M. (2002). Practical production of protein for food animals. In protein sources for the animal feed industry: Expert consultation and workshop, Bangkok, Thailand. pp. $77-124$.

De Silva, D. A. M. (2011). Value chain of fish and fishery products: origin, functions and application in developed and developing country markets. FAO, Rome. pp. 63.

FAO. (2018). The state of World fisheries and aquaculture. Meeting the sustainable development goals. FAO. Rome, Italy.

FAO. (2019). FishStatJ, a tool for fishery statistics analysis, Release: 3.5.0, universal software for fishery statistical time series. Global aquaculture production: Quantity 1950-2017; Value 1950-2017; Global capture production. FAO. Rome, Italy.

Fries, B. (2007). The value chain framework, rural finance, and lessons for TA providers and donors. Presentation at the international conference: Agriculture revolution: Financing the agricultural value chain, Mumbai, India.

Githukia, C. M., Drexler, S. S., Obiero, K. O., Nyawanda, B. O., Odhiambo, J. A., Chesoli, J. W., \& Manyala, J. O. (2020). Gender roles and constraints in the aquaculture value chain in Western Kenya. African Journal of Agricultural Research, 16(5), 732-745. https://doi.org/10.5897/AJAR2020.14783

Gitonga, K. (2014). Animal feed situation in Kenya: Report on assessment of commodity and trade issues for United States Department of Agriculture (USDA) Foreign Agriculture Service in the Global Agricultural Network.

Hasan, M. R., \& New, M. B. (2013). On-farm feeding and feed management in aquaculture. FAO Fisheries and Aquaculture Technical Paper No. 583. Rome, FAO. pp. 585.

Hasan, M. R., Hecht, T., De Silva, S. S., \& Tacon, A. G. J. (2007). Study and analysis of feeds and fertilizers for sustainable aquaculture development. FAO Fisheries Technical Paper No. 497. Rome, FAO. pp. 510.

Kaminski, A. M., Genschick, S., Kefi, A. S., \& Kruijssen, F. (2017). Commercialization and upgrading in the aquaculture value chain in Zambia. Aquaculture, 493, 355-364. https://doi.org/10.1016/j.aquaculture.2017.12.010

Kirimi, J. G., Musalia, L. M., \& Munguti, J. M. (2016). Effect of replacing fish meal with blood meal on chemical composition of supplement for Nile tilapia (Oreochromis niloticus). East African Agricultural and Forestry Journal, 82(1), 1-9. http://dx.doi.org/10.1080/00128325.2016.1158898

Kirimi, J. G., Musalia, L. M., Magana, A., \& Munguti, J. M. (2020). Protein quality of rations for Nile tilapia (Oreochromis niloticus) containing oilseed meals. Journal of Agricultural Science, 12(2), 82-91. https://doi.org/10.5539/jas.v12n2p82

KMT (Kenya Markets Trust). (2017). Mapping animal feed manufacturers and ingredient suppliers in Kenya.

KNBS (Kenya National Bureau of Statistics). (2020). Economic survey Nairobi. Kenya National Bureau of Statistics, Kenya. pp. 333.

Kok, B., Malcorps, W., Tlusty, M. F., Eltholth, M. M., Auchterlonie, N. A., Little, D. C., \& Davies, S. J. (2020). Fish as feed: Using economic allocation to quantify the Fish in: Fish-out ratio of major fed aquaculture species. Aquaculture, 528(2020), 735474. https://doi.org/10.1016/j.aquaculture.2020.735474

Kong, W., Huang, S., Yang, Z., Shi, F., Feng, Y., \& Khatoon, Z. (2020). Fish feed quality is a Key factor in impacting aquaculture water environment: Evidence from incubator experiments. Scientific Reports, 10(187) 1-15. https://doi.org/10.1038/s41598-019-57063-w

Kotler, P. (1997). Marketing management: Analysis, planning, implementation, and control (9th ed.). Prentice Hall, Upper Saddle River.

Kumar, G., \& Engle, C. R. (2016). Technological advances that Led to growth of Shrimp, Salmon, and Tilapia farming. Reviews in Fisheries Science and Aquaculture, 24(2), 136-152. 
https://doi.org/10.1080/23308249.2015.1112357

Kumar, G., Engle, C., \& Tucker, C. (2018). Factors driving aquaculture technology adoption. Journal of the World Aquaculture Society, 49(3), 447-476. https://doi.org/10.1111/jwas.12514

Liti, D. M., Fulanda, B., Munguti, J. M., Straif, M., Waidbacher, H., \& Winkler, G. (2005). Effects of open-pond density and caged biomass of Nile tilapia (Oreochromis niloticus L.) on growth, feed utilization, economic returns and water quality in fertilized ponds. Aquaculture Research, 36(15), 1535-1543. https://doi.org/10.1111/j.1365-2109.2005.01376.x

Munguti, J. M., Kim, J. D., \& Ogello, E. O. (2014a). An overview of Kenyan aquaculture: Current status, challenges, and opportunities for future development. Fisheries and Aquatic sciences, 17(1), 1-11. http://dx.doi.org/10.5657/FAS.2014.0001

Munguti, J. M., Kirimi, J. G., Obiero, K. O., Ogello, E. O., Kyule, D. N. Liti, D. M., \& Musalia, L. M. (2021). Aqua-feed wastes: Impact on natural systems and practical mitigations- A review. Journal of Agricultural Science, 13(1), 111-121. https://doi.org/10.5539/jas.v13n1p111

Munguti, J. M., Musa, S., Orina, P. S., Kyule, D. N., Opiyo, M. A., Charo-Karisa, H., \& Ogello, E. O. (2014b). An overview of current status of Kenyan fish feed industry and feed management practices, challenges and opportunities. International Journal of Fisheries and Aquatic Studies, 1(6), 128-137.

Munguti, J. M., Obiero, K. O., Orina, P. S., Musa, S., Mwaluma, J., Mirera, D. O., Ochiewo, J., Kairo, J., \& Njiru, J. M. (2017). State of aquaculture in Kenya. Laxpress Services, Nairobi, Kenya. pp. 133.

Munguti, J., Obiero, K., Odame H., Kirimi, J., Kyule, D., Ani, J., \& Liti, D. (2021). Key limitations of fish feeds, feed management practices, and opportunities in Kenya's aquaculture enterprise. African Journal of Food, Agriculture, Nutrition and Development, 21(2), 17415-17434. https://doi.org/10.18697/ajfand.97.20455

Musalia, L. M., Wangia, S. M. M., Shivairo, R. S., Okutu, P., \& Vugutsa, V. (2007). Dairy production within the smallholder dairy farmers in Western Kenya: Availability of dairy production inputs. In Annual workshop of the Animal Production Society of Kenya, Mtwapa, Kenya.

Nalwanga, R., Liti, D. M., Waidbacher, H., Munguti, J., \& Zollitsch, W. J. (2009). Monitoring the nutritional value of feed components for aquaculture along the supply chain-an East African case study. Livestock Research for Rural Development, 21(9), 1-12. Retrieved from http://www.lrrd.org/lrrd21/9/nalw21148.htm

Ngugi, C. C., \& Manyala, J. O. (2004). Aquaculture extension services in Kenya; Aquaculture extension services in Sub-Saharan Africa. Fisheries Department Circular No. 1002 FAO Fisheries Department Rome. pp. $35-42$.

NRC. (1993). Nutrients requirements of fish. National Academy Press, Washington, D.C., USA.

Nyandat, B. (2007). Analysis of feeds and fertilizers for sustainable aquaculture development in Kenya. In M. R. Hasan, T. Hecht, S. S. De Silva \& A. G. J. Tacon (Eds.), Study and analysis of feeds and fertilizers for sustainable aquaculture development (pp. 423-436). FAO Fisheries Technical Paper. No. 497. Rome, FAO.

Nyonje, B. M., Opiyo, M. A., Orina, P. S., Abwao, J., Wainaina, M., \& Charo-Karisa, H. (2018). Current status of freshwater fish hatcheries, broodstock management and fingerling production in the Kenya aquaculture sector. Livestock Research for Rural Development, 30(1), 1-15. Retrieved from

http://www.lrrd.org/lrrd30/1/mary30006.html

Obiero, K., Meulenbroek, P., Drexler, S., Dagne, A., Akoll, P., Odong, R., ... Waidbacher, H. (2019). The contribution of fish to food and nutrition security in Eastern Africa: Emerging trends and future outlooks. Sustainability, 1636(11), 1-15. https://doi.org/10.3390/su11061636

Ogello, E. O., Wullur, S., Sakakura, Y., \& Hagiwara, A. (2020). Dietary value of waste-fed Rotifer Brachionus rotundiformis on the larval rearing of Japanese whiting Sillago japonica. E3S Web of Conferences, 147, 01005. https://doi.org/10.1051/e3sconf/202014701005

Pomeroy, R., Navy, H., Ferrer, A. J., \& Purnomo, A. H., (2017). Linkages and trust in the value chain for small-scale aquaculture in Asia. Journal of the World Aquaculture Society, 48(4), 542-554.

https://doi.org/10.1111/jwas.12407

Porter, M. E. (1998). Competitive strategy: Techniques for analyzing industries and competitors (2nd ed.). New York: The Free Press (Simon and Schuster Inc).

Poulton, C., Gibbon, P., Hanyani-Mlambo, B., Kydd, J., Maro, W., Larsen, M. N., Osorio, A., Tschirley, D., \& 
Zulu, B. (2004). Competition and co-ordination in liberalized African cotton market systems. World Development, 32(3), 519-536. http://dx.doi.org/10.1016/j.worlddev.2003.10.003

Quagrainie, K. K., Amisah, S., \& Ngugi, C. C. (2009). Aquaculture information sources for small-scale fish farmers: the case of Ghana. Aquaculture Research, 40(13), 1516-1522. https://doi.org/10.1111/j.1365-2109.2009.02252.x

Quagrainie, K. K., Ngugi, C. C., \& Amisah, S. (2010). Analysis of the use of credit facilities by small-scale fish farmers in Kenya. Aquaculture International, 18, 393-402. https://doi.org/10.1007/s10499-009-9252-8

Sturgeon, T. J. (2001). How do we define value chains and production networks? IDS Bulletin, 32(3), 9-18. https://doi.org/10.1111/j.1759-5436.2001.mp32003002.x

Tacon, A. G. J. (2020). Trends in global aquaculture and aquafeed production: 2000-2017. Reviews in Fisheries Science \& Aquaculture, 28(1), 43-56. https://doi.org/10.1080/23308249.2019.1649634

Tacon, A. G. J., \& Metian, M. (2015). Feed matters: Satisfying the feed demand of aquaculture. Reviews in Fisheries Science and Aquaculture, 23(1), 1-10. https://doi.org/10.1080/23308249.2014.987209

Wangila, B. C. C., Hoorweg, J. C., \& Degen, A. (2007). Gender analysis of fish traders in the central coast inshore artisanal fisheries, Kenya. Journal of Science Technology Education and Management, 1(1), $42-54$.

\section{Copyrights}

Copyright for this article is retained by the author(s), with first publication rights granted to the journal.

This is an open-access article distributed under the terms and conditions of the Creative Commons Attribution license (http://creativecommons.org/licenses/by/3.0/). 